\title{
Impacts of Chinese economy and its global geopolitics: after the slowdown
}

\section{Impactos da economia chinesa e sua geopolítica global: depois da desaceleração}

Marcos Costa Lima'

DOI: 10.5752/P.2317-773X.2019v7.n2.p21

Received in July 16, 2017

Accepted in August 23, 2018

\begin{abstract}
This work present two main objectives: the first one, in addition to show the new centrality that Asia and East Asia regions represent today for the world economy, discusses the impacts of China's slowdown after 2013 for Asean countries and how the Chinese economy has been restructuring with its back to normal. The second objective indicates the main challenges that China faces today and analyzes whether China's expectations are maintained as a future systemic center in global geopolitics.
\end{abstract}

Key-Words: China's rising economy; China's back to normal; Asean economy vs. China; China's challenges; China geopolitics

\section{RESUMo}

Este trabalho tem dois objetivos centrais: o primeiro, além de evidenciar a nova centralidade que hoje representam a Ásia e a Ásia do Leste para a economia mundial, discute os impactos da desaceleração da China após 2013 com relação aos países da Ásia e como a economia chinesa se reestruturou com sua volta ao normal. O segundo objetivo indica os principais desafios que a China enfrenta hoje e analisa se as expectativas chinesas se mantêm como um futuro centro sistêmico na geopolítica global.

Palavras-Chave: A ascensão da economia chinesa; a volta da China à normalidade; Economia Asiática versus a China; Os desafios da China; a geopolítica chinesa

\author{
1. Prof. Dept. of Political Science, UFPE; \\ Ph.D. in Social Sciences, Universidade \\ Estadual de Campinas, UNICAMP, \\ Postdoctorate, University of Paris XIII \\ - Villetaneuse Coordinator of Institute \\ of Asia Studies-UFPE. Recife/ Brazil. \\ ORCID: 0000-0002-3831-7631. (iD)
}


Introduction

I defend the point of view that there is a difference between knowledge of other peoples and ages resulting in understanding, compassion, study and careful analysis in the interests of themselves and, on the other hand, knowledge - if that It comes to knowledge - integrated in a comprehensive campaign of self-affirmation, belligerency and declared war. There is, after all, a profound difference between the desire to understand for reasons of co-existence and enlargement of horizons, and the desire for knowledge for reasons of control and foreign domination. (SAID, 2007, p. 15)

This final decade of the XXIst century is changing rapidly, but keeping some standards in economy, politics and the environment. We are still living the impact of the 2008 crisis, with strong repercussions on a global scale, but whose core systemic insists on maintaining neoliberal policies in their central poles. Another major change comes from the East, represented by "China Rise". And now questions whether the return to normalcy in the country will change its expectations to replace the great hegemon that is the United States by 2030 (ARRIGHI, 2007). As Tsang ang Honghua (2016, p. 2) have said: "The decade under Xi's leadership, from 2012 to 2022, is going to be a pivotal one as he is determined to lead China towards national rejuvenation at a time when sustaining a fast rate of growth is becoming increasingly challenging. $\mathrm{Xi}$ intends to turn the rhetoric of the China Dream into reality". Which means convert China into a moderately prosperous society, accompanying the new global context of rapid change and preparing the country to transform itself from a regional power into a superpower, or at least into a global power.

According to the latest OECD report, (2018, p. 17), overall, growth in 2017 in Emerging Asia (Southeast Asia, China and India) is expected to remain strong. In 2017, growth in China and ASEAN is expected to pick up on a strong trade rebound and resilient domestic consumption while growth in India is anticipated to nudge down owing to taxation and monetary reforms. Over the medium term (2018-22), the region's growth is projected to remain robust, though slightly lower in comparison with the average pace between 2011 and 2015 .

These understandings, however, do not mean that the challenges facing China and Asia today, whether geopolitical, economic, social, and environmental, are not great. The environmental issue ${ }^{2}$, for example, a sensitive area of global change, is widely spoken and discussed, but pointed mitigating effects are still very far from presenting consistent results (TANG et al, 2015; ZHU et al, 2015; ZHANG, 2013; 2016). A significant and positive change was the development of developing countries into the world economy. According to Nayyar (2014), there was a dramatic change from 1970 to 2010, when the participation of these countries in global industrial production jumped from $1 / 12$ to $1 / 3$. Similarly, the share of world exports of manufactured goods rose from $1 / 12$ to $2 / 5$.

For the table below, the excellent performance of developing countries, especially between 2001 and 2008 shows that the Asian continent has been playing a decisive role, but also that global growth has been, since 1971, as a result of higher growth in developing countries. 
Table 1: Growth rates of the world economy by region 1971-2008

\begin{tabular}{l|c|c|c|c}
\hline \multicolumn{5}{c}{ Maddison data } \\
\hline & $1971-1980$ & $1981-1990$ & $1991-2000$ & $2001-2008$ \\
\hline Developing Countries & 5.23 & 4.07 & 4.93 & 6.41 \\
\hline Asia & 5.31 & 5.60 & 5.76 & 7.26 \\
\hline Africa & 4.01 & 2.22 & 2.67 & 5.01 \\
\hline Latin America & 5.57 & 1.34 & 3.19 & 3.52 \\
\hline Industrialised Countries & 3.34 & 2.89 & 2.58 & 1.91 \\
\hline World & 3.82 & 3.08 & 3.06 & 4.20 \\
\hline \multicolumn{7}{c}{ Source: MADDINSON (2007). } & & &
\end{tabular}

In Table 2 below, we compare the GDP indicators, Exports of goods and services and population of the three main centers of advanced economies - US, Euro and Japan with each other and what they represent to the world and then the same indicators for emerging economies - Russia, the emerging and developing Asia (29 countries), including China, India and Brazil also compared. But you can check what they represent to the world. At first, the GDP of Advanced represents $43.6 \%$ of global GDP, while the GDP of the emerging and developing economies, $56.4 \%$. The contrast is due to the number of countries: while the forwards are only 36 , the emerging 153 . But what is striking is the position of the emerging and developing Asia, which account for $28.7 \%$ of GDP, $16.9 \%$ of exports Goods and Services and are $48 \%$ of the world population. China alone represents $15.8 \%$ of world GDP, very close to the US and exports more goods and services than the US, $10.2 \%$ against $9.9 \%$ respectively in 2014 .

If we take into account the maintenance rates above $6 \%$ of GDP in China and the low rates that remain at the heart of the system, we see that China and Asia are approaching the economic hegemony of the US and European Union. The IMF itself points out that in terms of purchasing power parity (PPP) in US dollars, China has surpassed the US GDP, respectively 19,392,357 against 17,947,000 trillion.

Table 2: Classification of Advanced and Emerging Countries and its participation in the GDP; Export of Goods and Services and Population in 2013

\begin{tabular}{|c|c|c|c|c|c|c|c|}
\hline & \multicolumn{7}{|c|}{ GDP Goods and services Population Exports } \\
\hline & $\mathrm{N}^{\mathrm{o}}$ Countries & $\begin{array}{c}\text { Advanced } \\
\text { Economies }\end{array}$ & world & $\begin{array}{l}\text { Advanced } \\
\text { Economies }\end{array}$ & world & $\begin{array}{c}\text { Advanced } \\
\text { Economies }\end{array}$ & world \\
\hline Advanced Economies & 36 & 100.0 & 43.6 & 100.0 & 61.2 & 100.0 & 14,7 \\
\hline USA & 1 & 37.7 & 16.4 & 16.1 & 9.9 & 30.5 & 4.5 \\
\hline Euro & 18 & 28.2 & 12.3 & 40.4 & 24.6 & 32.0 & 4.7 \\
\hline Japan & 1 & 10.5 & 4.6 & 5.9 & 3.6 & 12.3 & 1.8 \\
\hline Emerging Economies & 153 & 100.0 & 56.4 & 100.0 & 38.8 & 100.0 & 85.3 \\
\hline Russia & 1 & 6.1 & 3.4 & 6.0 & 2.6 & 2.4 & 2.0 \\
\hline Emerging Asia & 29 & 50.9 & 28.7 & 43.5 & 16.9 & 57.3 & 48.8 \\
\hline China & 1 & 28.1 & 15.8 & 26.4 & 10.2 & 22.7 & 19.4 \\
\hline India & 1 & 11.8 & 6.6 & 5.3 & 2.0 & 20.8 & 17.7 \\
\hline Brazil & 1 & 5.2 & 3.0 & 3.1 & 1.2 & 3.4 & 2.9 \\
\hline
\end{tabular}

Source: IMF (2014, p. 163). 
3. The 10 countries of ASEAN: Thailand Philippines, Malaysia, Singapore, Indonesia, Brunei, Vietnam, Myanmar, Laos and Cambodia
The displacement of the dynamic axis of the world economy towards Asia Pacific had already been drawing for at least three decades (VEIGA; RIOS, 2010), from the rapid Japanese growth, followed by socalled Asian Tigers and soon after, the Flying geese and ending the unprecedented growth of China especially after 1978 and now in India. The region is thus decisively influencing the whole world economy.

To Medeiros (1997), China's rise in international trade has gained momentum since the 1980s, when a large expansion of regional trade was directly associated with foreign investments from the Asian financial centers, particularly from Hong Kong.

The objectives of the present work are: the first, in addition to presenting the new centrality that Asia now represents for the world economy, discusses the impacts of China's slowdown post 2013 for Asean and other countries in Asia and how the Chinese economy has been restructuring with its back to normal. The second objective analyzes whether China's expectations are maintained as future systemic center in global geopolitics, as its GDP has fallen from 9.3\% in 2011 to $7.4 \%$ in 2014 and $6.8 \%$ in 2015 . According to the IMF, this decreasing GDP trend will continue through 2018, when a recovery will occur.

Graphic 1 China Real GDP growth rate. (IMF)- 2011-2020

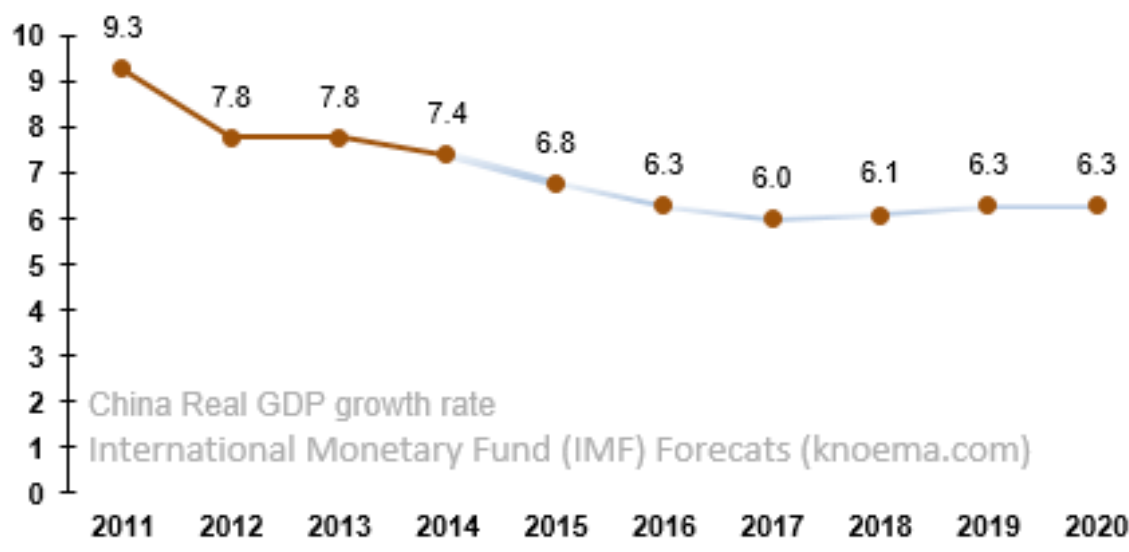

Source: IMF (2018a, s/p)

The real growth in emerging $\mathrm{Asia}^{3}$ (Southeast Asia, China and India) lived a gentle moderation in $2015,6.5 \%$, and is projected to remain so in the medium term to 2020 averaging $6.2 \%$ annually. China's growth will continue cooling while India will have the highest growth rates of GDP in the region. By 2015-2016, India GDP achieved - 7,93\%, surpassing China. But now is falling down. 
Graphic 2 GDP Growth of India -2012- 2017

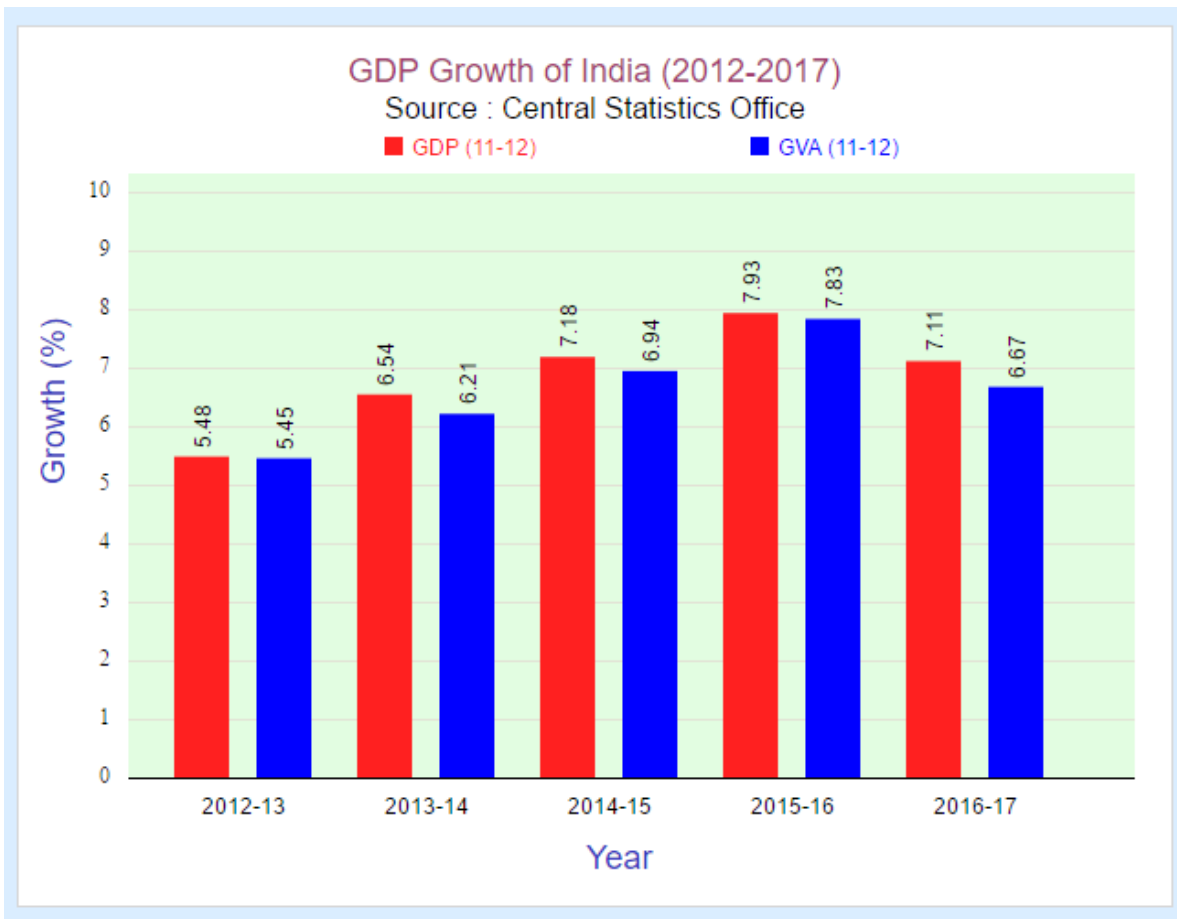

Source: OGD PLATAFORM INDIA (2018, s/p).

OBS: After following gross domestic product (GDP) for many years, policy makers have now also started looking at gross value added (GVA) to analyse growth.

The Growth in the ASEAN (Association of Southeast Asian Nations) will be slightly lower, averaging $4.6 \%$ in 2015 and $5.2 \%$ by 2020 , led by the Philippines and Vietnam. Private consumption is the largest contributor to overall growth, while exports contribute less than in the previous decade (OECD, 2018).

Because of the Asian Financial Crisis of the late 1990, the region felt the necessity of reassessing the inequality and poverty by considering that rapid economic growth was quite insufficient to face these challenges. In Indonesia, half of the population was vulnerable to poverty and hunger, caused by high food prices and unemployment, a problem that crossed all Asian countries but with great differences among them. In 2005, the Asean established The Asian Development Bank's Social Protection, reflecting that poverty needs to be faced via nationals programs for social protection. Many policies have been implemented since, but still appear timid to deal with the scale of the problem: in terms of poverty head count ratio at US $\$ 2$ per day in Purchasing Power Parity in 2010, Malasyia counts $2 \%$; Thailand $4 \%$; Indonesia $50 \%$; Lao PDR 65\%; Philipines $41 \%$; Vietnan $41 \%$ and Cambodja 50\%. among these countries, Indonesia, Lao PDR and Vietna were the ones that most drastically reduced poverty since 1992 (COOK; PINCUS, 2014).

The reduction in the pace of China will continue to affect the growth prospects of the rest of the region due to the decrease of Chinese imports and the decline of investment flows. Countries have different variations in their levels of exposure to the risks outlined.

The impact of the reduction of Chinese rhythm can be seen in various aspects, such as exports and Foreign Direct Investment (FDI). Exports 
4. The countries of ASEAN 5 are: Indonesia, Malaysia, Philippines, Thailand and Vietnan. are the first impact on the countries of ASEAN. Goods exported to China as part of the GDP of these countries are variable and range from $12 \%$ to Malaysia and 6-8\% for Singapore, Thailand and Vietnam; dropping to $3 \%$ for Indonesia and the Philippines. Exports of many of the ASEAN- $5^{4}$ countries are tightly integrated with China through regional production chains. Products exported to China for many ASEAN-5, countries-intensive Japan imported parts, South Korea and other Asian countries. But also, many of the exports from ASEAN-5 and other Asian countries to China are used to produce exports that go to other regions, not for final household. However, the most affected countries so far have been Malaysia, Singapore and Thailand (OECD, 2016). (SHIE, \& MEER, 2010)

The figure 1 Trade relations China and South Asian Economies - 2018 shows the trade relations of China with the South Asian Economies, and mainly five countries, in order, Vietnan, Singapore,Thailand, Malasia and Indonesia, perform 89\% of the total trade.

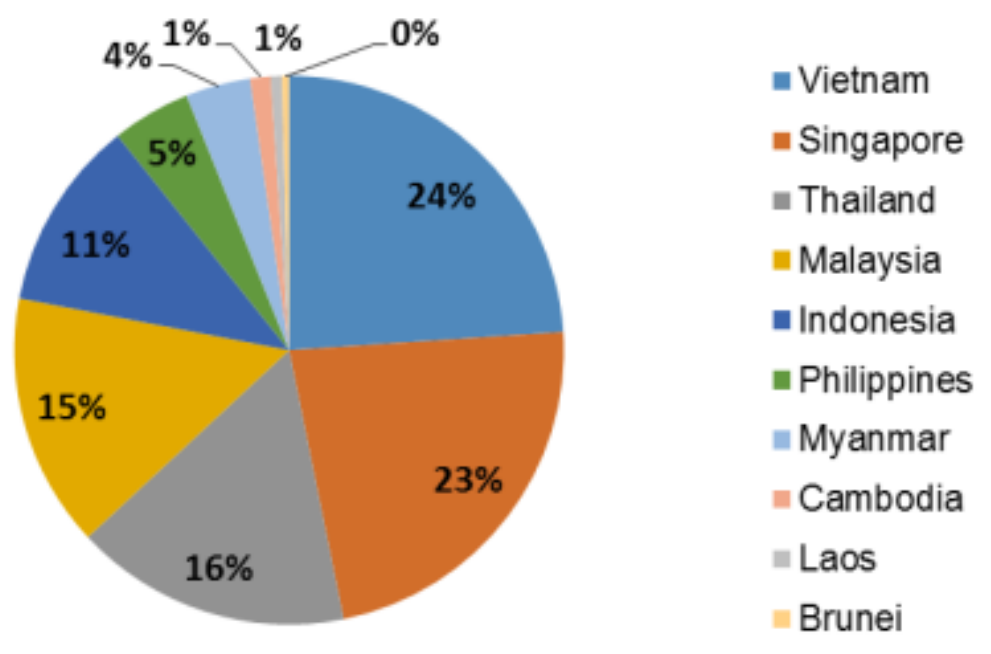

Source: $\mathrm{OH}(2017$, p. 2).

FDI is another complicating factor for the ASEAN as a result of reduced Chinese pace. China's FDI inflows into several ASEAN countries have been reduced and, since 2009, these investments had been an important source of foreign investment, particularly in Malaysia and Thailand, they end up compromising the growth of the same. The repercussions of this shrinkage can also impact domestic financial markets and may complicate macroeconomic management in these countries. Yet due to the Chinese cooling, can also aggravate capital flows of Asean as the US monetary policy has been more strict. The financial links between the countries of ASEAN and China can increase the risk of contagion from market fluctuations in China for financial markets of Asean (BAJPAI, 2016). 


\section{ASEAN}

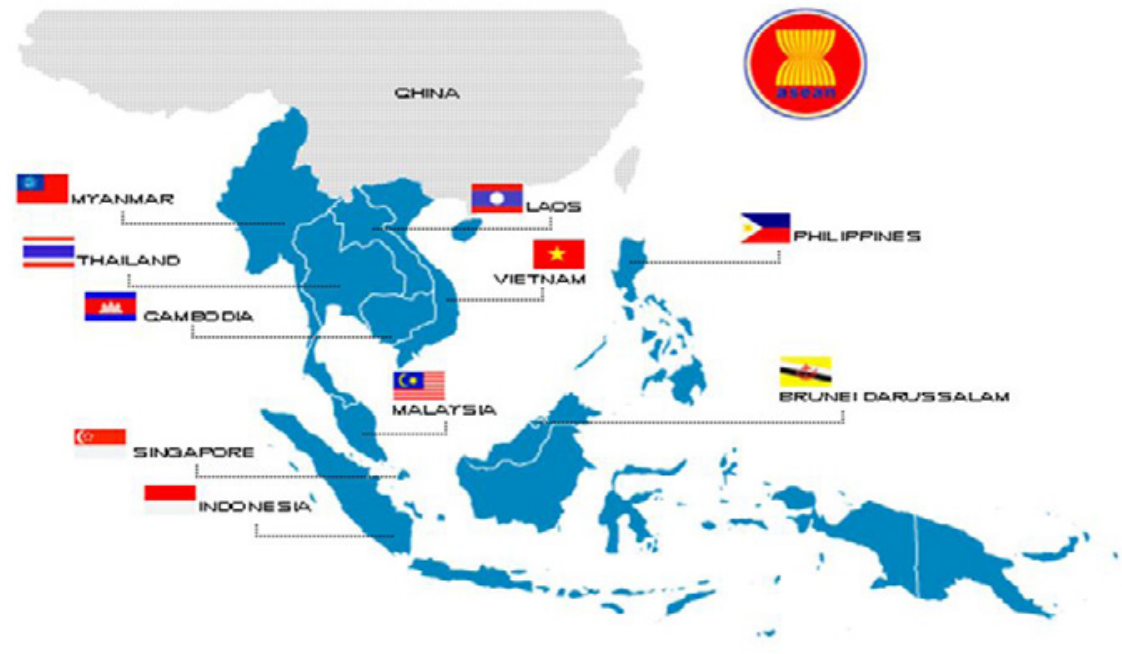

Source: ASEAN MARKET RESEARCH (2018, s/p).

The countries of ASEAN 5 are among the fastest growing in the world, but still have serious infrastructure problems, which are larger in Indonesia, the Philippines and Vietnam than in Thailand and Singapore, which have a higher per capita income. A likely contributing factor to the fall in the investment rate was the Asian crisis of 1997. But after the recovery, there was robust growth, and the ASEAN-5 countries have made great progress in poverty reduction, which significantly fell from the start 1990s, however, challenges remain. Taking a comparative perspective, Indonesia, Philippines and Vietnam still have considerable population living below the poverty line, while extreme poverty has become almost non-existent in Malaysia. In terms of income distribution, Malaysia and Thailand have Gini indices slightly higher than the others. Moreover, the inequality of average income has increased modestly in ASEAN-5. (OECD 2018; 2017; ASEAN 5..., 2019).

According to Seneviratne and Sun (2013), investments in infrastructure, both in quality and quantity, improved the result of the income distribution. However, investment by itself does not promote equality of income, which can be clearly observable in the region, by internal regional disparities with respect to energy and transportation. The capital -intensive investment, do not increase employment, and even the negligence towards environment.

ASEAN will celebrate 50 years of existence and since last year they are trying to promote inclusive and innovation-led economic growth to enhance the performance of the ASEAN Economic Community (AEC). In 2017, ASEAN members adopted the AEC 2025 Consolidated Strategic Action Plan to implement the 2025 AEC Blueprint. Endorsed by ASEAN economic ministers and the AEC Council, the Strategic Action Plan aims to foster regional integration by increasing trade and investment; 
integrating micro, small and medium-sized enterprises into the digital economy; and developing an innovation-driven economy. These measures reflect the main theme of the 30th ASEAN Summit in April 2017, "Partnering for Change, Engaging the World" (OECD, 2018).

However, as the OECD Report points out, the region suffer of underdeveloped infrastructure wich constrains the development of digital economy, and less than $30 \%$ of the population is on line in India, Indonesia and Cambodia, Lao PDR and Myanmar, wich have the fewer number of secure Internet servers for the population, less high speed broadband internet (except Indonesia), and relatively high Internet prices, a problem also in Philipines.The number of secure internet is higher in Singapore, but in the rest of the region is very different (OECD, 2018).

Graphic 1. Percentage of adults who are financially literate in Asia, 2014

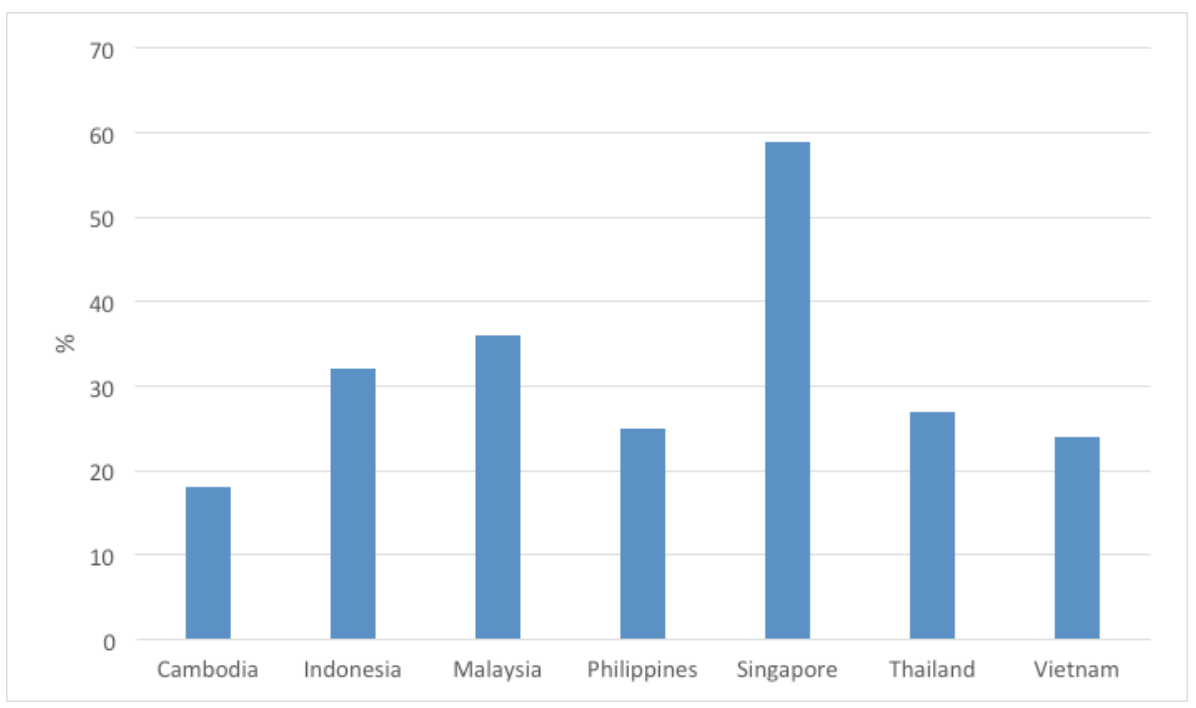

Source: Adapted from KLAPPER; LUSARDI; OUDHEUSDEN, (2014).

We can see that unless Singapore, the majority of the countries in the region present a very low literacy rate.

If the Chinese turbulence was, first, a demand shock to the ASEAN countries, it can be partially mitigated by domestic macro-economic policies. These countries may have room for fiscal and monetary stimulus able to sustain growth in the short term. But in the long term, China's back to normal may affect the production structure of these countries. One possibility is that rising wages in China has created incentives to shift production to intensive companies in labor, such as the textile sector, for these countries of ASEAN (OECD, 2018). Looking at table 3, we can see that with all the problems that affect the region, the average of GDP growth is still high, except for Brunei Darusslam and Singapore. Another point is that all the countries in the region should improve in secondary and tertiary education. 
Table 3: Real GDP Growth of Asean, China and India Annual percentage change

\begin{tabular}{|c|c|c|c|c|}
\hline & 2016 & 2017 & 2018-22 (average) & 2011-15 (average) \\
\hline \multicolumn{5}{|l|}{ ASEAN-5 countries } \\
\hline Indonesia & 5.0 & 5.0 & 5.4 & 5.5 \\
\hline Malaysia & 4.2 & 5.5 & 4.9 & 5.3 \\
\hline Philippines & 6.9 & 6.6 & 6.4 & 5.9 \\
\hline Thailand & 3.2 & 3.8 & 3.6 & 2.9 \\
\hline Viet Nam & 6.2 & 6.3 & 6.2 & 5.9 \\
\hline \multicolumn{5}{|c|}{ Brunei Darussalam and Singapore } \\
\hline Brunei Darussalam & -2.5 & 0.0 & 0.5 & -0.1 \\
\hline Singapore & 2.0 & 3.2 & 2.3 & 4.1 \\
\hline \multicolumn{5}{|l|}{ CLM countries } \\
\hline Cambodia & 6.9 & 7.1 & 7.2 & 7.2 \\
\hline Lao PDR & 7.0 & 6.9 & 7.1 & 7.9 \\
\hline Myanmar & 5.9 & 7.2 & 7.4 & 7.3 \\
\hline \multicolumn{5}{|l|}{ China and India } \\
\hline China & 6.7 & 6.8 & 6.2 & 7.9 \\
\hline India & 7.1 & 6.6 & 7.3 & 6.8 \\
\hline Average of ASEAN-10 & 4.8 & 5.1 & 5.2 & 5.1 \\
\hline Average of Emerging Asia & 6.4 & 6.4 & 6.3 & 7.1 \\
\hline
\end{tabular}

Note: The cut-off date is 31 October 2017. ASEAN and Emerging Asia are the weighted averages of those of the individual economies in these groupings. Data for India, Lao PDR and Myanmar follow fiscal years. The projections of China, India and Indonesia for 2017 are based on the results from the OECD Economics Department's ShortTerm Economic Prospects (STEP) Meeting in October 2017.

Source: OECD Development Centre, MPF-2018 (Medium-term Projection Framework). For more information on the MPF, please see www.oecd.org/dev/asia-pacific/mpf.htm

\section{Source: OECD (2018, p.17).}

Chinese economic growth already reduced a few years ago on the one hand, and on the other the recent turmoil in the stock market, raises suspicion that the economy is fragile. China accounts for $15 \%$ of global output and the effects of this reduction will be felt not only in Asean, as we have seen before, but in Japan, South Korea and Taiwan. Moreover, the impacts have been felt in Brazil and throughout Latin America.

In August 2015, the People's Bank of China (PBOC) surprised markets with three yuan consecutive devaluations, dropping 3\% in its value. Since 2005, the Chinese currency was appreciating (33\%) against the US dollar and this first devaluation marked the biggest drop in 20 years. The unexpected move was considered by many as an attempt by China to boost its exports, with China People's Bank stating that the devaluation is part of its reforms to direct savings to the market. (JOHNSTON, 2015).

Much of what has fueled the Chinese economy over the past three decades was based on a growth model driven by exports and investment in infrastructure, fueled by credit. But the weak external demand from rich countries and the level of total debt to $250 \%$ of GDP, which has nearly doubled since 2008 , is revealing the unsustainability of this model. To reverse the trend, Xi Jinping, China's president since 2013 has been preaching the return to "normal" for a more sustainable economy. This transition to an economy directed to technological advances, more oriented to the domestic market-oriented to the services sector, is causing immediate effect, although varied, on neighboring China (TSANG; HONGHAUA, 2016).

The countries of East Asia such as Japan, South Korea and Taiwan have pointed out the impact. The latter country, whose exports are directed by $40 \%$ to China, saw its growth rate of 3\% in 2015 fell to $1.65 \%$ 
5. China has, since 2014 , about $\$ 4$ trillion of US reserves. in 2016. Japan, which is a major supplier of industrial machinery, automobiles and other industrial products to China saw in the second half of 2015, a decrease of $4.4 \%$ in exports, while GDP growth contracted by $0.4 \%$. In South Korea exports fell 6.4\% in 2015 over the previous year. (OECD, 2018) Australia also felt the crisis, especially because of its dependence on commodities exports to China. Many mining companies see their annual profits drop by low demand from China. Indonesia, a country with over 261 million, has been resentful of the decline in investment, low job creation and tax revenues. Malaysia, meanwhile, was impacted by the drop in prices of its export of natural resources. (MATSUMOTO, 2019)

The countries of South Asia have fewer ties to the Chinese economy and the impact will be lower. Indian firms are less integrated with those of China and the country is not as dependent on external demand. Nevertheless, India's growth has been accelerated and the expectations are that grow up in China in the coming years. (CUI, 2007).

But, what are the impacts on the US economy?

China is the largest export economy in the world. In 2016, China exported $\$ 5.29$ trillion and imported $\$ 3.41$ trillion, resulting in a positive trade balance of $\$ 1.88$ trillion. By 2016 China's GDP was $\$ 11.2$ trillion and its GDP per capita was \$15.5 Thousand. The main export destinations of China are the United States ( $\$ 385$ billion), Hong Kong (\$287 billion), Japan (\$129 billion), South Korea (\$93.7 billion) and Germany (\$ 65.2 billion). The top import origins are Hong Kong ( $\$ 285$ billion), South Korea (\$ 124 billion), the United States (\$115 billion). (OEC, 2017).

Table 4 US Trade Goods with China - 2014-2017 (billions US)

\begin{tabular}{c|c|c|c}
\hline & Exports & Imports & Balance \\
\hline TOTAL 2017 & $130,369.5$ & $505,597.1$ & $-375,227.5$ \\
\hline TOTAL 2016 & $115,602.1$ & $462,618.1$ & $-347,016.0$ \\
\hline TOTAL 2015 & $115,932.0$ & $483,188.7$ & $-367,256.7$ \\
\hline TOTAL 2014 & $123,657.2$ & $468,474.9$ & $344,817.7$ \\
\hline
\end{tabular}

Source: US CENSUS (2018).

The value of goods and services purchased by the Chinese in the US in 2014, as we see in table 4, reached 123.65 billion dollars, which corresponds to $5.3 \%$ of US exports. However, China is the first global exporter to the US with a value reached 468.474 billion dollars. Also in 2014, representing $16.4 \%$ of US imports. Thus the US trade balance with China is in deficit and this deficit is financed in part by China's capital flows. Only in four years trade, the value of balance trade pro- China exceeds 1.434 .416 trillion USD. I mean, China is the largest US lender, keeping most of US Treasury bonds, and the Foreign Exchange Reserves represent in may 2018 US\$ 3.134 Trillion 5 .

The decrease in Chinese consumer spending level will affect US exports negatively, it will have to seek other markets to allocate its exports, which may result in a fall in GDP of this country, at least in the short term. With the reduction of imports by Chinese and maintaining 
the export level to the US, there will be increase in the deficit in the trade balance at least in the short term. According to the OECD, $2 \%$ of Chinese domestic demand drop will cause a drop of $0.3 \%$ in US GDP in 2015 and 2016.

Another form of injury to the US relationship with China will be the Chinese go to sell US treasury bonds. The Chinese government may sell the bonds, for example, heat its economy and make new investments. A massive sale of these securities will be a major threat to the US, it would take prices to a sharp drop (FLOYD, 2015).

US companies that generate a significant portion of its revenues from China are likely to be adversely affected due to lower domestic demand in China. The result would ultimately affect not only the holders of securities of these companies but layoffs and increased unemployment.

But the drop in the pace of China's economic growth would cause not only negative effects in the US, such as the fall in oil prices. Since China is the world's largest importer of the product, 7.4 million barrels per day in 2015, the tendency is to fall and the US being the world's second largest importer, or 7.2 million barrels in 2015, lower prices have a positive effect on its trade deficit, when the cost to import oil would be reduced, but with harmful effects for countries that depend on oil export. (BARRON, 2018).

The major challenges of China

If not expected major negative impacts on the whole of the rich regions - the United States especially and the European Union who lives already one since 2008 crisis, the biggest concern for 2016 is mainly with China, since its rapid growth, so important from the early, now it is reduced dramatically. Its economy has cooled the impetus and after an average growth of almost 10 percent between 2006 and 2014, growth was 6.8 percent in 2015 and is expected to fall to 6.3 / 6.5 percent in 2016. But the real concern is that the slowdown in China could easily generate a new recession. That's why China is the most obvious source of uncertainty for the world economy in 2016

Optimists believe that China will manage this transition smoothly. Unfortunately, this will be difficult. Investments expenditure are more volatile than consumers spending: they are subject to fall faster than consumer spending. Moreover, the growth model based on investment in China has been financed by huge amounts of debt. Again, there is an unsustainable feedback loop in operations of state banks that collected large masses of savings of Chinese families, paying artificially low interest rates on them. They have funneled this cheap capital for companies with political connections, which have duly feasted with the volume of investments. While these loans and investments continued at high speed, they were sufficient to sustain the growth rate, which in turn kept the default rate at a reasonable level. But once the music stops, the debt will no longer be reimbursed. Default rates will jump; banks will suffer losses. If banks react lending less, growth will slow further and the default rate will increase. (WOLF, 2018). 
Anyway, the robust economic growth in China over the past two and half decades made it a global economic grow th engine. Statistics show that China is the largest exporter of goods, and their purchases represent about $10 \%$ of global trade. Not only that, China was responsible for more than one third of oil demand growth until recent times and even most of the copper demand. The country is one of the world's largest manufacturing center, and therefore received the title of "the world factory". Overall, China has multiplied its trade and financial links with the world over the years. And this time when it is experiencing a slowdown, the international impact is very large. Its economy recorded fast growth in twenty-five years untill 2009, and the prospects are to decrease to $6,5 \%$ untill 2020. Its exports recently dropped by $25 \%$, then a year earlier, while imports fell by almost $14 \%$. The economic growth of other countries, particularly those that rely on orders from China ends up being harmed (BAJPAI, 2016).

Table 5 China: Composition of GDP (gross domestic product) across economic sectors from 2006 to 2016

\begin{tabular}{c|c|c|c|c|c|c|c|c|c|c|c}
\hline & $\mathbf{2 0 0 6}$ & $\mathbf{2 0 0 7}$ & $\mathbf{2 0 0 8}$ & $\mathbf{2 0 0 9}$ & $\mathbf{2 0 1 0}$ & $\mathbf{2 0 1 1}$ & $\mathbf{2 0 1 2}$ & $\mathbf{2 0 1 3}$ & $\mathbf{2 0 1 4}$ & $\mathbf{2 0 1 5}$ & $\mathbf{2 0 1 6}$ \\
\hline Agri & $11.11 \%$ & $10.77 \%$ & $10.73 \%$ & $10.33 \%$ & $10.1 \%$ & $9.25 \%$ & $9.4 \%$ & $9.3 \%$ & $9.1 \%$ & $8.8 \%$ & $8.6 \%$ \\
\hline Ind & $47.95 \%$ & $47.34 \%$ & $47.45 \%$ & $46.24 \%$ & $46.72 \%$ & $44.37 \%$ & $45.3 \%$ & $44 \%$ & $43.1 \%$ & $40.9 \%$ & $39.8 \%$ \\
\hline Serv & $40.94 \%$ & $41.89 \%$ & $41.82 \%$ & $43.43 \%$ & $43.19 \%$ & $46.38 \%$ & $45.3 \%$ & $46.7 \%$ & $47.8 \%$ & $50.2 \%$ & $51.6 \%$ \\
\hline \multicolumn{10}{c}{ Source: STATISTA (2019). }
\end{tabular}

6.See also POLUIÇÃO DO AR..., 2015 and OSTERATH, 2018.
Construction and industry (including mining, manufacturing, electricity, water the largest and gas) accounted for $44 \%$ of China's GDP in 2013. The industry was the main contributor until 2010, when the service sector by pass in 2011 and in 2016 achieved 51.6\%. The OECD report (2018) that we are using for this information, points out three major challenges for China, the environment, human capital and rural development.

On the environment, high levels of pollution are known in large Chinese cities, which are not few (LIMA, SILVA; ALVES, 2014). In December 2015 air pollution again reached record levels in China. Ten cities decreed red alert, the most serious, with levels of toxic particles up to 30 times higher than the maximum tolerated, according to the World Health Organization (HAN et al, 2018). One hundred million Chinese were told to stay home. And for the first time, an entire province, Shandong, went on red alert. Another 50 cities have issued orange alerts, with worrying levels of pollution. China has suffered for decades with severe pollution ${ }^{6}$. With an economy based on coal made the country the world's largest $\mathrm{CO} 2$ emitter. In recent years the particle levels in the air and smog have become alarming and forced the Chinese government to recognize the problem and announce emission reduction measures. Earlier this year, $90 \%$ of Chinese cities could not fit in quality levels of air determined by the Chinese government itself.

With all the implications of the problem for human health, China continues to massively use coal, whose burning releases carbon monoxide, carbon dioxide and other harmful gases. Chinese President Xi Jinping said recently that the country's $\mathrm{CO} 2$ emissions, which coal is the largest 
source, will reach its peak in 2030. Greenpeace reports that the country has to approve the construction of 155 new coal plants in 2015. (GALENOVICH, 2018)

The recognition by the government of the serious effects of pollution, human and economic costs, has led to reforms. Measures taken to improve air quality has had some results in reducing urban pollution, but still very insufficient.

China is the world leader in industrial production, including mining and mineral processing, processed metals, petroleum, cement, coal, chemicals and fertilizers. It is also a leader in manufacturing machinery, armaments, textiles and clothing. The country is the largest manufacturer of consumer products, a leader in food processing, and a major manufacturer of telecommunications equipment. It is a growing manufacturer of automobiles, railway equipment, ships, aircraft and even spacecraft, including satellites (BAJPAI, 2014).

Graphic 2: China Industry Value Added (\% GDP) 2006-2016

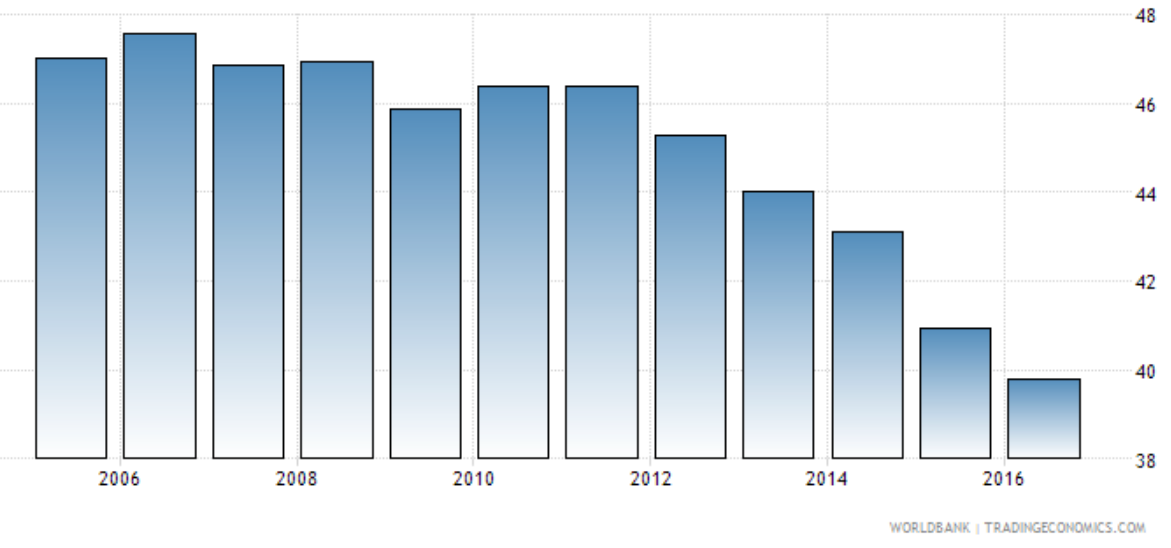

Source: OECD (2015).

The industry value added dropped down substantively from $47 \%$ in 2006 to $40 \%$ in 2016, a fall that reflects the slightest presence of GDP among the sectors. The Chinese Human Capital will have a tendency to be improved, as the country seeks to intensify innovation and knowledge intensive industries. The OECD (2015) considers that even people with higher qualifications in the country are not sufficiently prepared for the demands of a market that is gaining complexity and sophistication.

The skills considered "soft", linked to management positions, communication and negotiation, among others, today regarded as the most urgent, are not generally obtained in universities. Recognizing these deficiencies, it is understood that vocational education offers ways to improve the practices, the government has invested in the intensification of training in the workplace. Also sustain greater interaction between universities and the industrial sector. The National Centers of Technology Transfer (NTTC) have acted as intermediaries between universities and industry to spread innovations. And with much more autonomy, they are able to patented technology market, thus increasing the rate of patents produced by universities. New training programs and attracting world-class researchers and other highly skilled workers, has helped to 
support the need and search for new innovations. A so called National Medium Shot Talent Development and Long-Term (2010-2020), has operated to attract and retain individuals with high qualification in six priority areas: political leaders and cadres of government, business entrepreneurs technical, industry managers, skilled agricultural workers and social service agents (OECD, 2018)

Chinese R\&D investment has grown remarkably over the past two decades. It is now the second-largest performer in terms of R\&D spending, on a country basis, and accounts for 20 percent of total world R\&D expenditure, with the rate of R\&D investment growth greatly exceeding that of the U.S. and the EU (OECD, 2018).

Figure $1 \mathrm{R} \& \mathrm{D}$ spending in billions of dollars (current, in purchasing power parity terms) 1981-2013

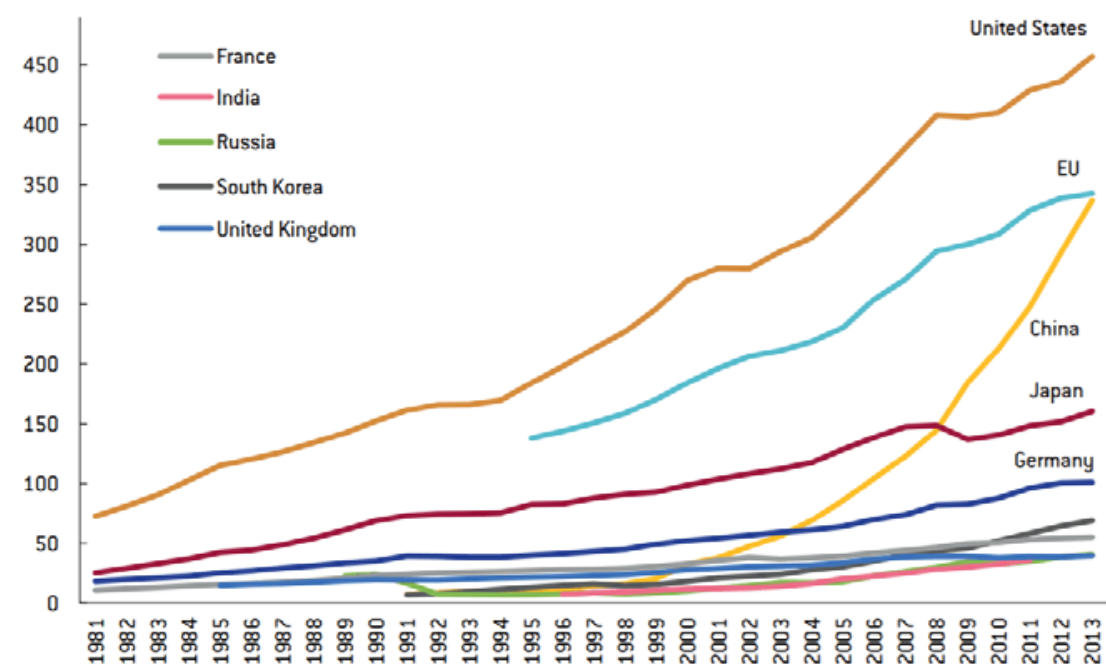

Source: Bruegel based on NSF [2016). PPP = purchasing power parity. NOTES: Foreign currencies are converted to dollars through PPPs. Some country data are estimated. Countries are grouped according to the regions described by The World Factbook, www.cia.gov/library/ publications/the-world-factbook/.

Source: OECD (2018).

Table 4: The Rise of China in Science

\begin{tabular}{c|c|c|c}
\hline & $\begin{array}{c}\text { Share of world scientific } \\
\text { papers 2003 }\end{array}$ & $\begin{array}{c}\text { Share of world scientific } \\
\text { papers 2013 }\end{array}$ & $\begin{array}{c}\text { Average annual growth rate } \\
\text { in scientific papers 2003-13 }\end{array}$ \\
\hline US & $26.8 \%$ & $18.8 \%$ & $7.0 \%$ \\
\hline EU & $31.0 \%$ & $25.4 \%$ & $4.9 \%$ \\
\hline Japan & $7.8 \%$ & $4.7 \%$ & $1.7 \%$ \\
\hline SKorea & $2.0 \%$ & $2.7 \%$ & $10.4 \%$ \\
\hline China & $6.4 \%$ & $18.2 \%$ & $18.9 \%$ \\
\hline
\end{tabular}

Source: VEUGELERS (2017, p. 2)

7. The 10 largest agricultural producers in the world are: China, USA, Brazil, India, Russia, Mexico, Japan, Germany and Turkey. But the biggest exporters are: USA, Canada, France, Brazil, Italy, Netherlands, China, Belgium, Germany, United Kingdom.
The table 4 gave evidence of the rising position of China in ten years in terms of share of scientific paper, getting very close to the US and EU. Maintaning the annual growth, in few years China will overcome them.

China is the world's largest agricultural economy, with agriculture, forestry, animal husbandry and fisheries accounting for about $8.6 \%$ of its GDP, in 2016. This percentage is much higher than developed countries 
like the US, UK and Japan, where agriculture accounts for about $1 \%$ of GDP. The chart below shows the evolution of the share of agriculture in GDP (1983-2013). Although the percentage has gradually decreased over the years, it still accounts for about $34 \%$ of the total employed population. Over the past seven years, the share of agriculture as a share of GDP remained more or less stable. (DEPTAMENT OF AGRICULTURE, FOOD AND THE MARINE, 2018).

The economic reforms of 1978 changed the face of agriculture in China. Before these reforms, four out of five Chinese were working in agriculture. But that changed with the property rights in the field, which led to grow th small businesses do not farm in rural areas. The de-collectivization, along with better prices for agricultural products, led to higher productivity and a more efficient use of labor. The other major change occurred in 2004 when the agricultural sector began to receive greater support in a major shift in economic policy in which the government has to support the sector policies rather than overwhelming it, as I used to. (HUANG; YANG; ROSSELLE, 2010).

Rural development is considered as the third challenge, since the rural areas did not suffer the same modernization that the urban areas, although the gap has been reduced. The productivity in rural areas is seen as critical and to narrow this gap, you need more support to rural areas. Agricultural productivity will have to be extended through mechanization and investments. The credit assistance and facilitation of land reallocation are laying the foundation for improved productivity. But the attempt to prevent the depletion of these lands and the excessive use of pesticides are major challenges. The government should increase the training of farmers and reduce subsidies for fertilizers that contaminate not only groundwater but also rivers and drinking water.

The Chinese Geopolitics and Concluding remarks

One issue that has gained the world specialized media is where will move the economy, global geopolitics, ambitions and influence of China - the aim of the Communist Party to maintain a standard of "medium-high growth" (6.5\%) until 2020 will become attainable?

From the military point of view, even with the braking, China has motivation and resources to keep growing this sector even more rapidly than its neighbors and even the US. The legitimacy of the Communist Party is, in good measure, pressed by the "great rejuvenation of the nation" - a concept that includes the claim on the islands that are in dispute, the airspace and the expansion of the South and East China seas. President Xi Jinping, has amply demonstrated its interest in pursuing his goal, in part by accelerating the transformation of the People's Liberation (BLACKWILL; CAMPBELL, 2016) into a world-class fighting force with operations well beyond Asia.

A less aggressive economy should increase the importance to Beijing to maintain a peaceful regional environment so that it can expand trade and investment with its neighbors. The paradox is that the top leaders of China have deliberately encouraged its population in a nation- 
8. Beijing has established 40 billion USD for the Silk Road Fund to the land initiatives / sea megaproject. alist propaganda, which has resulted in a growing expectation of public opinion of the country to sovereignty claims in the East Sea and the South China.

From the point of view of international institutions under US leadership since World War II, it is evident the great efforts made by the Chinese in seeking to consolidate multilateralism, where significant examples are the BRICS and the Bank of the BRICs and the creation of the Bank Asian Investment in Infrastructure (Baii). On the other hand, the gigantic project One Belt One Road, with estimates of more than \$ 1 trillion investment in infrastructure projects, which will require many years for its implementation. If successful, it will create a powerful economic belt across Eurasia, which also articulates with the maritime Silk Road ${ }^{8}$ .This is one of the key projects of China's foreign policy today, which will connect China to Europe and Africa by land and sea routes passing consequently a number of countries of Central Asia and the Middle East. The Chinese dream to regain the lead when it comes to international trade is what prompted the Beijing government to the creation of this project, and the way in which China intends to deal with the other actors in the implementation and realization of the same is at least different from the way that the current hegemon - the Unite $d$ States of America - deal with this issue (BARBOSA et al, 2016).

The so call Silk Maritime Route begin in Quanzhou in the province of Fujan, and also reach Guang, Guandong province, Beihai (Guanxi) and Haikou (Haina), before heading to the Strait of Malacca, Kuala Lumpur; it will address Calcutta, India, and then cut the rest of the Indian Ocean to Nairobi, Kenya and following to Sri Lanka. From Nairobi, the sea route will go north around the "Horn" of Africa and from there to the Red Sea and the Mediterranean, with a stop in Athens before reaching the Earth's Silk Route in Venice.

According to Hilpert and Wacker (2015, p. 2), which feature the wide arc of projects, trade and investment agreements established in recent years by China, China's new leadership builds a proactive foreign policy, much stronger, to shape their own environment, far beyond what remain just reacting to events. "Economic diplomacy plays a central role. Geographically, the priorities are based on what is defined as a "great neighborhood" where Xi Jinping speaks of a "community of shared interests, destination and responsibility", or a "Target Community ". For the authors, with this immense project platform, China demonstrates to be inclined to take a much larger global and regional responsibility.

This pro activism is justified as an attempt to counteract the creation of two large free trade agreements between the European Union and the United States, (TTIP) Transatlantic Trade and Investment Partnership, and the second among the 12 APEC countries including the US and Japan, Transpacif Partnership (TPP). The latter, especially, is for the Chinese a US attempt to harm it economically through trade diversion and isolate it in Asia, its own region. (Carneiro, F.Lirio, 2018) 
Route Map of Silk Road One Belt One Road

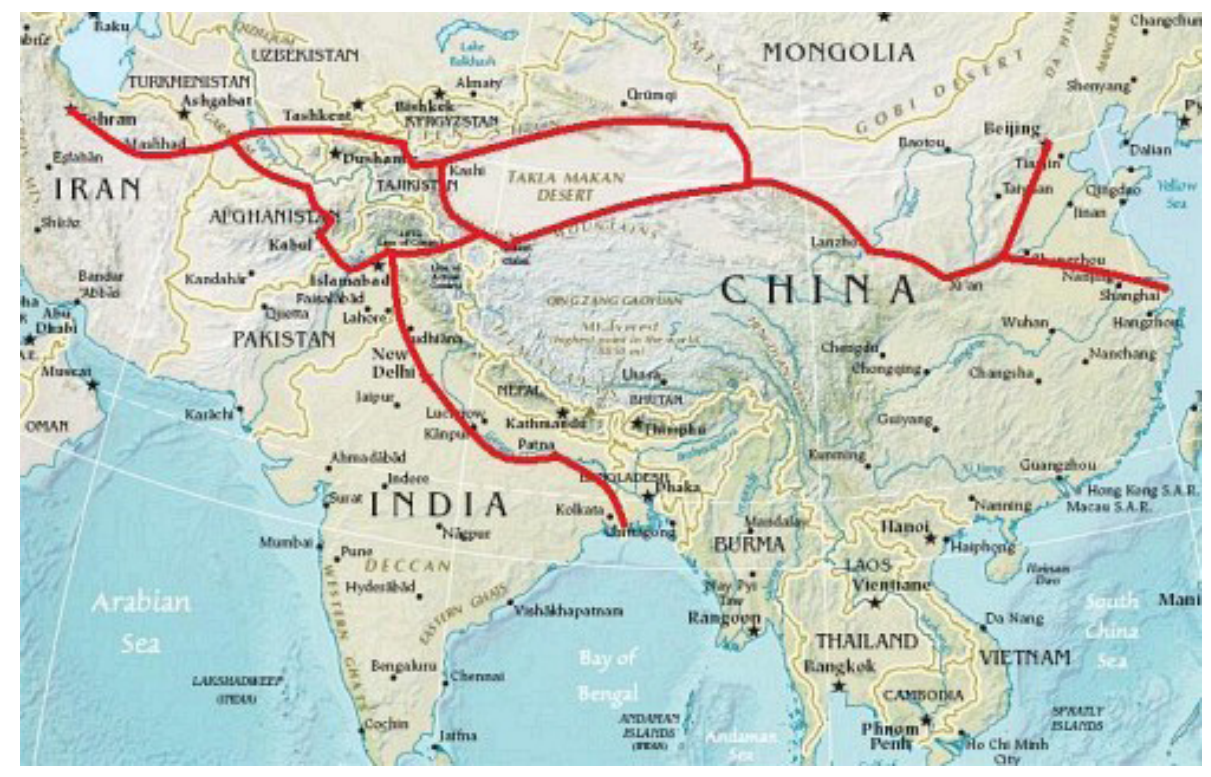

Sources: ITALY PLANS TO... (2019). ${ }^{9}$

This true effervescence by which China is passing, despite its "back to normal" economy, is also reflected in the culture and production of knowledge. The magnitude and importance that the country gained after the victory of the revolution led by Mao Zedong, has caused Chinese social scientists to reflect on the making of their academic subjects, hitherto very subordinate to the Western codex.

Is emerging in the field of International Relations, one called "Chinese School" of thought that seeks to merge political realism aspects and economic liberalism adopted in RI's, with the works of philosophy and great thinkers of pre-Qin dynasty ${ }^{10}$, as the Confucius and Sun Tzu, which are the basis and influence for the way of life adopted by China nowadays. Moreover, the fact that China is a communist country also influences the creation of this Theory of International Relations (BARBOSA et al, 2016).

Barry Buzan wrote in 2010 an exciting and dense article about the possibilities and challenges that China has to maintain its rise peacefully. The author, unlike Measheimer (2010) and Fred Halliday, (2000), believes that the project is feasible, however, that will be much harder than it has been in the last three decades; China will have to strongly think about it even on its internal issues and the international society in which today is one of the largest players. These processes, in a crisis even without a clear and definite insight, will create strong tensions - for example, with the United States and Japan, without being able to repeat its successful experience since 1978. The country is better positioned than most of the great powers to do well and cannot keep a comfortable distance of the problems now faced by the West U.S. (US VS CHINA..., 2013). Whether or not, it will be demanded for an international action that can be at the height of their current conditions of a great power. In this sense, the dimension of peace and the categorical statement this premise ${ }^{11}$ may represents, is an invaluable overcoming to the capitalist crisis (BUZAN, 2010, p. 34; LIMA, 2016a).
9.See also HONG, 2015.

10. The year $221 \mathrm{BC}$ is often referred to as the time when China was unified in the form of a large kingdom or empire, although there are already several states and dynasties before that. Successive dynasties developed bureaucratic control systems that would allow the Chinese emperor administer the vast territory that was to become known as China.

11. Inside China is emerging an effort to promote some of the principles inspired by Confucio toward building a more collectivist order, a harmonious alternative to the conflictual individualism that took account of Western thought of international relations (YAOING, 2012; XIA0, 2009). 
12. According to Zheng Yongian (2010) that modern Chinese international order is a fusion of traditional elements of Tianxia with Western elements of international order. All international Chinese relations were conducted through a tax system. As a practical way, the system of taxes was largely organized by idea-state of China, or Tianxia, which can be translated as "all under heaven", which covered the neighbors where China was in the center.

Tiaxia is a cultural concept of ancient China that denotes both the geographical world and the metaphysical realm of

mortals, and later became associated with political sovereignty. In ancient China, Tianxia denoted the land, space and area divinely attributed to the emperor by universal principles and well-defined

order. The center of this land was directly attributed to the imperial court, forming the center of a worldview that was centered in the imperial court and was concentrically out, major and minor officials, and then ordinary citizens, tax states and, finally ending with the fringe of the "barbarians."

The main concept of Tianxia is closely associated with civilization and order in

Chinese classical philosophy, and formed the basis for the worldview of the

Chinese people and nations influenced by them, at least since the first millennium before Christ. Tianxia has been applied independently by other countries in the cultural sphere of East Asia including Japan, Korea and Vietnam.

13. See the debate of John Mearshei mer and Yan Xuetong on the subject: Can China Rise Peacefully? on https:// youtu.be/wBrA2TDcNto
So, it is encouraging that the Chinese Academy works towards rescue, in international relations, of a immense country's tradition, in building a "Chinese School". The Chinese tradition is consistent in this direction. As has been said by Qin Yaqing (2012), the theory feeds on a certain culture, developing and subsequently gaining universality by interaction with other cultures. Thus, taking the perspective of the concept of tian xia ${ }^{12}$ (world order) and the practice of a system of taxes, backed a deep structure of over 3,500 years, allowing the country to study the size of wide civilization. The ideas of harmony, peace, cooperation are important values in Chinese culture, which are in addition to Confucian thought, according to which human nature is correctable or potentially ready for good. The Confucian Humanism Hsiung (2010) says that what determines the effect of human nature is that the condition of the human environment (society), can be perfected by moral education.

This tradition is welcome, when the array of Western political theory, structured in capitalism, says the opposite, in the famous phrase of Hobbes on the "Wolf of the Man". The last paper of the prestigious Prof. Yan Xuetong (2018), considering that liberalism is losing its strength, is moving in a direction that gives reason to a chinese pacific ascent ${ }^{13}$.

\section{References}

ARRIGHI, G. Adam Smith em Pequim: Origens e Fundamentos do Século XXI. São Paulo: Bomtempo, 2007, cap.9.

ASEAN 5 (ASEAN-5) Economic Statistics and Indicators. Economy Watch. 2019. Available at: $<$ http://www.economywatch.com/economic-statistics/country/ASEAN-5/>. Accessed on: Feb. 20, 2019

ASEAN MARKET RESEARCH. General Overview, 2018. Available at: <http://www.aseanmarketresearch.com/services.html>. Accessed on: Oct. 20, 2018.

BAJPAI, P. China's GDP Examined: A Service-Sector Surge. Investopedia, oct. 31, 2014. Available at: <https://www.investopedia.com/articles/investing/103114/chinas-gdp-examined-servicesector-surge.asp $>$. Accessed on: Oct. 29, 2018.

BAJPAI, P. The Biggest Losers From China's Slowdown. Investopedia, mar. 11, 2016. Acessed on: Oct. 25, 2018.

BARBOSA, M. P. et al. Nova Rota da Seda e a Ascensão Pacífica da China. NEARI em Revista, v. 2, n. 2, p. 31-51, 2016. Available at: <http://www.faculdadedamas.edu.br/revistafd/index.php/ neari/article/download/388/372>. Accessed on: Sept. 28, 2018.

BARRON, J. China surpassed the United States as the world's largest crude oil importer in 2017. US Energy Information Administration, feb. 5, 2018. Available at: <https://www.eia.gov/todayinenergy/detail.php?id=34812 >. Accessed on: Oct. 25, 2018.

BLACKWILL, R. D; CAMPBELL, K. M. Xi Jinping on the Global Stage: Chinese Foreign Policy under a powerful but exposed leader. Washington DC; New York: The Council on Foreign Relations, feb. 2016. 66 p.

BUZAN, B. China in International Society: Is 'Peaceful Rise' Possible? The Chinese Journal of International Politics, v. 3, issue 1, p. 5-36, 1 mar. 2010.

CARNEIRO, Flávio Lyrio, "Parceria Trans-Pacífico: um acordo megarregional na fronteira da regulação do comércio internacional?” Brasília: IPEA, 2018 Texto para Discussão, nº 2108.

COOK, S.; PINCUS, J. Poverty, Inequality and Social Protection in Southeast Asia: An Introduction. Journal of Soyheast Asian Economics, v. 31, n.1, p. 1-17, apr. 2014. Available at: <https:// www.jstor.org/stable/i40128775>. Accessed on: Aug.t 18, 2018.

CUI, L. China’s Growing External Dependence. F\&D, v.44, n. 3, 2007.

DEPARTAMENT OF AGRICULTURE, FOOD AND THE MARINE. Review and Outlook for Agriculture, Food and the Marine, 2018. Ireland. [S.1: s.n]. Available at: https://www.agri- 
culture.gov.ie/media/migration/publications/2018/AnnualReviewandOutlook2018310818.pdf. Accessed on: November 11, 2018.

FLOYD, D, Global Impact of China's Geopolitical Strategy. Investopedia, jul. 28, 2015. Available at: <https://www.investopedia.com/articles/investing/072815/global-impact-chinas-geopolitical-strategy.asp >. Accessed on: Jul. 13, 2018.

GALENOVICH, A. Environmental Policy in China: Can China Address Air Pollution and Climate Change? Is There Environmental Awareness in China? DAO IPCI, nov. 2018. Available at: $<$ https://medium.com/dao-ipci/environmental-policy-in-china-can-china-address-air-pollution-and-climate-change-de0f762f53e1>. Accessed on: Jul. 06, 2019.

HALLIDAY, F. International relations theory and the post-cold war period. METU Studies in Development, v. 27, n. 3-4, p. 235-263, 2000. Available at: <http://www.acarindex.com/dosyalar/makale/acarindex-1423910150.pdf>. Accessed on: Sept. 15, 2018.

HAN, Lijian et al. Multicontaminant air pollution in Chinese cities. Bull World Health Organ., p. 96-233, 2018. Available at: <https://www.who.int/bulletin/volumes/96/4/17-195560.pdf > Accessed on: Mar. 20, 2019.

HILPERT, H. G.; WACKER, G. Geoeconomics meets Geopolitics: China's new economic and Foreign Policy Initiative. German Institute for International and security Affairs, v. 33, jun. 2015. Available at: <https://www.swp-berlin.org/fileadmin/contents/products/comments/2015C33_hlp_wkr.pdf>. Accessed on: Sept. 10, 2018.

HONG, Zhao. China's new Maritime Silk Road: Implications and Opportunities for Southeast Asia. Institute of Southeast Asian Studies, n. 3, 2015.

HSIUNG, J. C. A re-appraisal of Abrahamic values and neorealist IR theory: From a Confuncian-Asian perspective. In: YONGNIAN, Z. (Ed.). China and International relations. The Chinese view and the contribution of Wang Gugwu. London: Routledge, p. 17-41, 2010. Available at: $<$ http://www.eria.org/Chapter\%204\%20China.pdf >. Accessed on: Jun. 06, 2019.

HUANG, Jikun; YANG Jun; ROZELLE, Scott. Changing Food Consumption Pattern and Demand for Agri-based Industrial Products in China: Implications for Southeast Asia's Agricultural Trade. Center for Chinese Agricultural Policy, 2010. Available at: <http://www.eria.org/ Chapter\%204\%20China.pdf >. Accessed on: Jun. 06, 2019.

IMF. Data Mapper. China Real GDP Growth Rate, Many years. 2018a.

IMF. World Economic Outlook. Washington DC: International Monetary Fund, 2014.

IMF. World Economic Outlook. Washington DC: International Monetary Fund, 2018.

ITALY PLANS TO join Belt Road Initiative. China Daily, mar. 06, 2019. Available at: $<$ https:// www.chinadailyhk.com/articles/49/14/181/1551886564019.html>. Accessed on: Mar. 20, 2019.

JOHNSTON, M. Slow Growth in China to Affect Asia-Pacific. Investopedia, sept. 3, 2015. Accessed at: <http://www.investopedia.com/articles/investing/090315/slow-growth-china-affect-asiapacific.asp\#ixzz4F4olLIFY>. Accessed: Aug. 03, 2018.

KLAPPER, L.; LUSARDI, A.; OUDHEUSDEN, P. V. Financial Literacy Around the World: Insights from the Standard \& Poor's Ratings Services Global Financial Literacy Survey. [S.l: s.n], 2014. Available at: <https://gflec.org/wp-content/uploads/2015/11/Finlit_paper_16_F2_singles.pdf $>$. Accessed on: Sept. 20, 2018.

KLEIN, N. This Change Everything. Capitalism vs. The Climate. New York: Simon \& Schuster, 2015.

LIMA, M. C. Introdução: a ascensão chinesa. In: LIMA, M. C. (Org.). Perspectivas Asiáticas. Rio de janeiro: Centro Internacional Celso Furtado, 2016.

LIMA, M. C.; SILVA, J.; ALVES, J. R. C. Territory, development and the economy of large cities - Perspectives of Brazil and China. In: The Harmony of Civilizations and Prosperity for All? China and the World: Tradition, Reality and Future. Beijing: Beijing Forum, 2014.

MADDINSON, A. Contours of the World Economy: 1-2030 AD. Essay in Macroeconomic History. Oxford: Oxford University Press, 2007.

MATSUMOTO, Fumi. China, Indonesia and India emerge as miners of Australia's coal. Nikkei Asian Review, mar. 17, 2019.

MEARSHEIMER, J. The Gathering Storm: China's Challenge to US Power in Asia. The Chinese Journal of International Politics, v. 3, n.4, Winter, 2010. Available at: <https://academic. oup.com/cjip/article/3/4/381/439228>. Accessed on: Sept. 07, 2018. 
MEDEIROS, C. A. Globalização e inserção internacional diferenciada da Ásia e América Latina. In: TAVARES, M. C.; FIORI, J. L. Poder e dinheiro. Uma economia política da globalização. Rio de Janeiro: Vozes, p.279-356, 1997.

MIRZAYEV, E. Impact of the Chinese Economy on the U.S. Economy. Investopedia, apr. 29, 2019. Available at: <https://www.investopedia.com/articles/investing/072915/impact-chinese-economy-us-economy.asp\#ixzz4F4nBz5XZ>. Accessed on: Oct. 10, 2018.

NAYYAR, D. A Corrida pelo Crescimento: Países em desenvolvimento na economia mundial. Rio de Janeiro: Centro Internacional Celso Furtado/Contraponto, 2014.

OBSERVATORY OF ECONOMIC COMPLEXITY (OEC). China. 2018. Available at: <atlas.media.mit.edu/pt/profile/country/chn/>. Accessed on: May 20, 2018.

OECD. Economic Outlook for Southeast Asia, China and India 2017: Addressing Energy Challenges. Paris: OECD Publishing, 2017. Available at: <http://dx.doi.org/10.1787/saeo-2017en>. Accessed on: Jul. 08, 2019.

OECD. Economic Outlook for Southeast Asia, China and India 2018: Fostering Growth Through Digitalisation. Paris: OECD Publishing, 2018. Available at: <http://dx.doi. org/9789264286184-en>. Accessed on: Oct. 05, 2018.

OECD. Economic Outlook for Southeast Asia, China and India: Enhancing regional ties. Paris: OECD, 2015. Available at: <https://www.oecd-ilibrary.org/development/economic-outlook-for-southeast-asia-china-and-india-2015_saeo-2015-en>. Accessed on: Oct. 05, 2018.

OGD PLATAFORM INDIA. Central Statistics Office. 2018. Available at: <https://data.gov.in/ keywords/central-statistics-office>. Accessed on: Oct. 18, 2018.

$\mathrm{OH}$, Yoon Ah. China's Economic Ties with Southeast Asia. World Economy Brief, v.7, n. 18, sept. 4, 2017.

OSTERATH, B. Dip in China's CO2 emissions sparks cautious optimism. DW, jul. 02, 2018. Available at: <https://www.dw.com/en/dip-in-chinas-co2-emissions-sparks-cautious-optimism/a-44491772>. Accessed on: Oct. 25, 2018.

POLUIÇÃO DO AR na China atinge novos recordes e com milhões são afetados. O Globo, dec. 26, 2015. Available at: <http://oglobo.globo.com/sociedade/poluicao-do-ar-na-china-atinge-novos-recordes-cem-milhoes-sao-afetados-18368123\#ixzz4FXgHhZEC>. Accessed on: Jul. 06, 2018.

SAID, E. Orientalismo: O Oriente como invenção do Ocidente. São Paulo: Companhia das Letras, 2007.

SENEVIRATNE, D.; SUN, Y. Infrastructure and income Distribution in Asea-5: what are the links? IMF Working Paper, v. 13, n. 41, feb. 2013. Available at: <http://citeseerx.ist.psu.edu/ viewdoc/download?doi=10.1.1.278.6841\&rep=rep1\&type=pdf $>$. Accessed on: Sept. 25, 2018.

SHIE, V. H.; MEER, C. D. Is this the Asian Century? China, India, South Korea and Taiwan in the Age of Intellectual Capitalism. Journal of Contemporary Asia, v. 40, n. 1, pp. 1-21, feb. 2010.

STATISTA. China: distribution of gross domestic product (GDP) across economic sectors from 2008 to 2018. [S.l: s.n], 2019. Available at: <https://www.statista.com/statistics/270325/distribution-of-gross-domestic-product-gdp-across-economic-sectors-in-china/>. Accessed on: May 28, 2018.

TANG, X. et al. Dilemmas for China: Energy, Economy and Environment. Sustainability, v. 7, n. 5, p. 5508-5520, 2015. Available at: https://www.mdpi.com/2071-1050/7/5/5508>. Accessed on: Sept. 10, 2018

TSANG, S.; HONGHUA, M. (Eds.). China in the Xi Jinping Era. Nothingham China Policy Institute Series. Basingstoke: Palgrave Macmillan, 2016.

U.S. VS CHINA: Battle to be the largest economy in the world. Investopedia, mar. 20, 2013. Availabre at: <http://www.investopedia.com/articles/investing/032013/us-vs-china-battle-belargest-economy-world.asp\#ixzz4FjErnRKL>. Accessed on: Oct. 15, 2018.

US CENSUS. Trade in Goods with China. 2018. Available at: <https://www.census.gov/foreign-trade/balance/c5700.html>. Accessed on: Mar. 28, 2018.

VEIGA, P. da M.; RIOS, S. P. A Emergência Asiática e a América Latina: implicações econômicas atuais e prospectivas. [S.1]: Plataforma Democrática, working paper, n. 8, jul. 2010. Available: $<$ http://www.plataformademocratica.org/Arquivos/A\%20emergencia $\% 20$ asiatica $\% 20 \mathrm{e} \% 20$ a\%20America\%20Latina.pdf >. Accessed on: Jun. 07, 2018.

VEUGELERS, R. China is the world's new science and technology powerhouse. Brink Asia, aug. 30, 2017. Available at: <http://bruegel.org/2017/08/china-is-the-worlds-new-science-andtechnology-powerhouse/>. Accessed on: May 28, 2018. 
WOLF, Martin, "China's debt threat: time to rein in the leading boom". Financial Times, 25, July, 2018

XIAO, R. Toward a Chinese school of International Relations? In: GUNGWU, W.; YONGNIAN, Z. (Eds.). China and the New International Order. London: Routledge, 2009.

XUETONG, Y. Chinese Values vs. Liberalism: What Ideology Will Shape the International Normative Order? The Chinese Journal of International Politics, v. 11, issue 1, p. 1-22, mar. 1, 2018. Available at: <https://doi.org/10.1093/cjip/poy001>. Accessed on: Oct. 10, 2018.

YAQING, Q. Chinese Culture and Its Implications for Foreign Policy-making. Chine Institute of International Studies, 2012. Available at: <http://www.ciis.org.cn/english/2011-11/18/content_4634967.htm>. Accessed on: July 15, 2016.

YONGIAN, Z. Organizing China's inter-state relations. From "tianxia" (all-under-heaven) to the modern international order". In: YONGNIAN, Z. (Ed.). China and International relations. The Chinese view and the contribution of Wang Gugwu. London: Routledge, 2010.

ZHANG, J. Foreign Direct Investment, Governance and the Environment in China. Regional Dimension. Nothingham China Policy Institute Series. Basingstoke: Palgrave Macmillan, 2013.

ZHANG, J. Striking Balance between Environmental Protection and Rapid Development. In: TSANG, S.; HONGHUA M. (Eds.). China in the Xi Jinping Era. Nothingham China Policy Institute Series. Basingstoke: Palgrave Macmillan, p. 151-186, 2016.

ZHU, J. et al. China’s Environment: Big issues, Accelerations Effort, Ample opportunities. Jul. 13, 2015. 